\title{
Biafra in the Present: Trauma of a Loss
}

\author{
Olajide Oloyede \\ Research in Anthropology and Sociology of Health (RASH) \\ Department of Anthropology and Sociology \\ University of the Western Cape, Cape Town, South Africa \\ E-mail:ooloyede@uwc.ac.za
}

\begin{abstract}
This paper forms part of a wider attempt at engaging the issues of nation-building, war, and trauma within the context of a developing sociology of trauma. It focuses, specifically, on Biafra, a recurring issue in the political and economic discussions in Nigeria. It delimits the focus to trauma. The Igbo perception of their increased marginalisation in the scheme of things in contemporary Nigeria brings to the fore the idea of Biafra, an Igbo attempt to create an Igbo nation-state which subsequently resulted into the war which foreshadowed many of the conflicts that would threaten to 'shatter' many post-colonial Africa. The war was traumatic: it inflicted fear and suffering. With the use of cultural trauma and the notion of the loss of assumptive world, the paper suggests that its loss was more traumatic because of the shattering of the cognitive representation of Biafra, an entity which was to bring a sense of belonging and connection that would cohere the Igbo being. In the wake of the loss of Biafra, the assumptive world of the Igbo was shattered. The paper suggests further that current recollection of Biafra by the Igbo serves as an illustration of the 'collective trauma' of its loss. The theoretical basis for the argument in this paper is that Biafra is rooted in the psyche of the Igbo.
\end{abstract}

Keywords: trauma, assumptive world, Igbo, Biafra, nation building

\section{Introduction}

This paper addresses a past unsettled; one that political discourse of the present brings alive in the collective and individual memory. In the discourse is a reminder of things unsettled, the recollection of which is an excursion into meaning reconstruction in the context of a perceived marginalisation. The focus is on Biafra, a nation almost brought into existence, yet exists in the psyche of a people and whose loss in the sense of not being brought to existence, is one of a 'shattered assumption'. The paper addresses this 'shattered assumption' and brings out the 'trauma', not of war but what was at war that never in the end was. It looks at some of the issues relating to the 'trauma of loss' pointing to 
the importance of reading the dynamics of remembrance within the context of social and political practices. The goal is to contribute to the debate on the critical notion of nation building with its attendant war and violence inquiring into the 'assumptive world' of a people. The paper shows how recollection of Biafra, which foreshadowed the conflicts that would threaten to 'shatter' many post-colonial states in Africa, is bounded up with contemporary power relations and political arrangements in Nigeria. Though Biafra is past, it is one that never passes away and 'recounted'by a collective that considers it pregnant with respect to its present life.

The point that Biafra is alive is one that is frequently made in the analysis of contemporary politics in Nigeria (see for example the contributions by Amadiume, Ezeigbo, Ikpeze in Amadiume, 2000; Smith,2005) Smith (2005: 42), writes that "collective memories about Biafra are being revitalised, reinscribed, and surely, to some degree, reinvented. As Nigeria tries to forge its way forward in the post-military era, Igbos feel compelled to put the issues of Biafra back on the table because, from their perspective, adequate representation and influence in a civilian government, so dominated by networks of patronage, depend upon redressing issues of marginalisation that have their roots in Biafra."Whilst Smith's observation is correct, especially the Igbo perception of their marginalisation in the scheme of things, the rooting of the marginalisation in Biafra, which echoes the prevailing discourse of the perceived Igbo marginalisation in the country, is somehow off the mark.

A similar remark can be made in relation to an earlier observation by Ikpeze, (2000), who provided a history of marginalisation before the Biafra war. He made a distinction between the British colonial administration's marginalisation of all ethnic groups in Nigeria, a feature of marginalisation before the war and marginalisation of the Igbo, an ethnic group by other ethnic groups in Nigeria, specifically, the Hausa-Fulani and the Yoruba. His observation would seem somehow correct but not quite. What would be the case is that the British colonial administration laid the foundation for the perceived Igbo marginalisation in its 'divide-and-rule' policy which favoured the North in relation to the South of the country. I'll return to this later in the paper but will argue that the perception of marginalisation formed part of what underlay the crisis that led to the Biafra war in the first place; its loss only deepened the perception. One can suggest also that current engagement with Biafra can be read as a process of confronting the trauma of its loss for the Igbo. For over two decades, as many commentators (see for example, Harneit-Sievers and Emezue, 2004; Amadiueme, 2004) have pointed out, there was silence on Biafra; a silence which was officially-induced and sanctioned as the following statement (in Amadiueme, 2000: 41) by the then Head of State, General Gowon attests: 
"The so-called rising sun of Biafra is set forever. It will be a great disservice for anyone to continue to use the word Biafra to refer to any part of the East Central of Nigeria. The tragic chapter of violence is just ended. We are at the dawn of national reconciliation. Once again, we have an opportunity to build a new nation" (Yakubu Gowon (1970:37)

The silence that followed was to deny the Igbo and indeed the country as a whole the opportunity to express the suffering brought about by the war, in the case of the Igbo and the necessary reflection by ordinary Nigerians. This would have eased, arguably, to a considerable degree, the present anxieties among the Igbo and their perceived marginalisation would possibly have been dampened. Indeed, it is what was lost, Biafra, as distinct from the perceived marginalisation, which is the real source of present anxieties among the Igbo. In other words, Biafra, an 'assumptive world' of the Igbo was shattered; this shattering, a trauma in itself continues to surface in critical moments such as when issues of revenue allocation and political arrangements are discussed. The questions arise: how does the theory of assumptive world help us to understand Biafra as a traumatic loss? What is it about Biafra that makes its loss traumatic? What does Biafra mean for the Igbo? The paper discusses these questions. The immediate circumstances leading to the war and the key social actors that played an active role in the build-up are also discussed. The discussion draws on some of the significant pieces of research and reflective articles that have been written on Biafra.

The paper has three sections: an introductory section which presents the main conceptual frame of discussion. In this section, the key notion of 'assumptive world' is discussed in relation to cultural trauma, the core discursive concept. A justification for its use is discussed in the section. This forms the basis for the second section which charts Biafra as what was lost by a people, the Igbo; here, a brief history of the war is provided followed by a discussion of what Biafra means in the socio-psychology of the Igbo. In this discussion, is a highlight of the experience of the Igbo within the broader context of the history of the formation of a Nigerian nation-state. This is very crucial in the task at hand. It is very important to bear the following remark in mind: it is not Biafra as war, a historical event, that qualifies it as trauma but Biafra as an 'assumptive world' that was shattered. The last section examines the trauma of the loss of Biafra followed by a brief concluding remark.

\section{Conceptual clarification: assumptive world and cultural trauma}

The discussion of individual trauma would seem inevitable as it allows a better understanding of the core concepts of assumptive world and cultural trauma. 
The starting point of such a discussion of trauma is, in very many cases, Freud. One sees, for example, his understanding of traumatic neurosis in the work of Caruth, a prominent trauma theorists. Such a strategy will not be applied here because the objective is not to provide a review of trauma. The discussion of individual trauma is confined to the aspects that have immediate relevance to cultural trauma. As has been remarked by various writers (see for example, Alexander, 2004; Kansteiner, 2004; McNally, 2003), trauma has become one of the key interpretative categories of contemporary politics and culture. It is a conceptual tool with historical application and moral specificity concerned with concrete psychological dynamics set in motion by events (Kansteiner, 2004). It is, as the extensive literature shows, a widely applied conceptual tool whose application goes beyond psychoanalysis and psychology.

As an essentially psychological phenomenon, its effects and symptoms have been extensively discussed using various approaches that range from autobiographical accounts, personal testimony in fictional narratives, literary studies and short-piece public reflections. In all these, there is one common understanding: trauma is largely taken as the shattering of the victim's basic assumption of him/herself and the world.

There is, similarly, an acknowledgement that the issues thrown up in the various discussion of trauma do have significant bearing on the construction of identity (Stocks, 2007; Zelizer, 2002). In general, a discernable central thread in most of the writings about trauma is the adherence to the simple point that psychological trauma results from an extremely disturbing event, an experience which fractures the apparently coherent self (Stocks, 2007) or shatters ones worldview (Jannoff-Bulman, 1992; Everly, 1995; Leys, 2000). As suggested by Janoff-Bulman, whose work will be discussed later, the disturbing event has three characteristics: it is out of the ordinary, directly experienced and perceived as a threat to survival and self-preservation.

What is thus perceived as trauma consists of overwhelming life events that pose intense threats to both biological and symbolical survival and generate terror (Leys, 2000). In other words, events are experienced in such a way as to induce an intense psychological crisis.

These events, it has been variously shown, inflict fear and suffering, induce pain, anguish, fear, loss and grief and bring about the destruction of a 'coherent and meaningful reality' thus pushing the traumatised to the limit, as phrased by psychoanalysts. Therefore, by definition, "trauma overwhelms our abilities to cope and adjust, calling into question the most basic assumptions that organise our experiences of ourselves, relationships, the world and the human conditions itself" (Landsman, 2002:13). The general assumption in these writings is that trauma is the experience of the individual's emotional, cognitive being and a 
"crisis of meeting" (Lietchy, 2002).

It is undoubtedly clear and indeed common knowledge that trauma generally refers to individuals. However there are, of recent, highly significant and influential writings on trauma that have ascribed it to a group (Alexander 2004; Zelizer, 2002, Olick, 1999; Caruth, 1996). When ascribed to a group, it is phrased as 'collective trauma' or 'cultural trauma' (see Payne et al, 2004, for an extensive review) and in many cases, an association is made between the two. In these writings, collective trauma would imply, in a rather simple sense, trauma that affects a group with, as Smelser (2004) puts it, "definable membership". Neal (1998), like many other writers noted earlier, has suggested that it has a bearing on identity and as Smelser (2004), citing Erikson (1994) points out, any given trauma may be community-disrupting and identity-disrupting or community-solidifying and identity-solidifying but could be a mixture of both. Trauma is perceived therefore as a cultural trauma when members with a sense of belonging to a collective such as state, ethnic or religious group feel they have been subjected to a fearful and painful event that leave marks upon their collective consciousness and memory. The association between collective trauma and cultural trauma appears to be made in perceiving cultural trauma thus. In fact, Smelser (2004: 44) highlights the association when he states that "the idea of collective trauma, collective memory, and collective (e.g. national) identity are so frequently associated with one another in the literature on socio-cultural trauma." Some writers couple cultural trauma and identity with notions of what being a member of a certain community means (Zlizer, 2002). As Alexander (2004:1), one of the foremost 'collective trauma' theorists outside psychology and psychoanalysis, puts it, cultural trauma occurs "when members of a collectivity feel they have been subjected to a horrendous event that leaves indelible marks upon their group consciousness, marking their memories forever and changing their future identity in fundamental and irrevocable ways." When these horrendous events cause the death of innocent victims, they engender traumatic bereavement and may trigger a process of collective bereavement in which the grieving involves the larger society (Piver and Prigerson, 2005). Furthermore, these events have an impact on the future of the collective. The defining word is collective hence, the association usually made with cultural trauma. But does this reference to collectivities render trauma cultural? This is a question that has become a main and indeed, most powerful critique of Alexander's conceptualisation. The question is asked further as to whether one can yield something fruitful in making sociological of what is essentially a psychological concept. Here, the reference is to Hans' (2005) perceptive critical engagement with Alexander's notion of cultural trauma. In his words, "But is the approach conceptually and theoretically viable - or does it lead astray and neglect 
the true potential of psychological trauma research for historical sociology?"

The validity of this question does not, in my view, rob cultural trauma of its utility. Its analytical power might be considered the critical issue of objection which is somehow justified. However, such an objection would seem tempered if one accepts Smelser's (2004) sharpening of the concept of cultural trauma when he brings in 'memory', which Eyerman (in same volume as Smelser's piece) discusses in detail. For Smelser, cultural trauma is "a memory accepted and publicly given credence by a relevant membership group and evoking an event or situation which is a) laden with negative effect, b) represented as indelible, and c) regarded as threatening a society's existence or violating one or more of its fundamental cultural suppositions" (Smelser, 2004: 44). One sees in Smelser, a definition of cultural trauma that roots it socio-psychologically, via collective memory, in Durkheim's conscience collective. He suggests that "a cultural trauma refers to an invasive and overwhelming event that is believed to undermine or overwhelm one or several essential ingredients of a culture or the culture as a whole" (Ibid: 38), thus distinguishing it from individual trauma.

Caution is called for in making a distinction between cultural trauma and individual trauma to avoid what Alexander (2004) calls 'naturalistic fallacy', which is the analogical transfer of the psychoanalytical model of individual trauma to the study of the collective memory. Alexander uses this phrase to warn against the assumption that events themselves create trauma in his attempt to deal with the tension, as Hans (2005: 367) puts it "between the psychological definition of trauma and his definition of cultural trauma." The "naturalistic fallacy" that Alexander refers to would seem evident in the growing body of work on Trauma which tends, somehow, to craft an imprecise concept of cultural trauma that yields little insight. This point is instructive for the present discussion which is neither a focus on the event, the Biafra war, nor individual experience of the war. As was pointed out in the early part of this discussion, trauma, at the level of the individual, is generally conceived as a psychic injury caused by an overwhelming experience of a catastrophic event, where the memory of the event is repressed and the response occurs in an often delayed, uncontrolled repetitive fashion (Caruth, 1996:11; Olick, 1999:343). As the discussion also highlights, individual trauma tends to be defined as a 'pathological state' requiring psychoanalysis to bring it back to its original state (Lifton, 1995). The underlying assumption, as can comfortably be said, is the existence of a psychic unity which becomes shattered by unassimiliable event and requiring of integration. This would seem to apply both to individual psychological trauma and collective trauma. However, in the case of collective trauma, Alexander suggests, rather emphatically, that it is discursively constructed and distinct from psychic trauma. In effect, it is a socially constructed process and includes several issues around which the 
narrative about the trauma is developed.

It is noticeable that event is central in both individual psychological trauma and cultural trauma. Though in Alexander's social constructionist trauma thesis, events are not inherently traumatic, what makes them so, are the cultural template through which the traumatised experience them. However, for Smelser (2004), several definitional accomplishments must be made before an event can qualify as cultural trauma: it must be remembered, or be made to remember. In addition, the memory must be made culturally relevant, that is, represented as obliterating, damaging, or rendering problematic something sacred - usually a value or outlook felt to be essential for the integrity of the affected society. Finally, the memory must be associated with a strong negative affect, usually disgust, shame or guilt.

In dealing with trauma in this paper, the focus is not with the events which are traumatic but the 'objects' to which one attaches oneself, which slip away from one's 'clutches'. These 'objects' are meaningful and are part of the core of one's being. Biafra as war, an event, was traumatic because it inflicted fear and suffering, induced pain, anguish, resulted in the loss of close ones and property; Biafra, as a 'meaningful object' to which there was and still is cognitive attachment was traumatic because it slipped away inducing loss and destruction of an aspect of Igbo being. The one could be said to be an experience of an event, a concrete experience of the victim, the traumatised; the other, the 'representation' of loss of a self, an identity, or a loss of an aspect of a self/identity. Both have distinctive qualities and affect individual's and collective's fundamental assumption. The former implies a recollection, a remembrance of the event. To remember trauma in this way, as the trauma literature shows, is to bear witness and give testimony (Niemeyer, 2001). It involves, one may add, like the latter, an active process of interpretation and meaning-creation. The focus here is not with understanding of the experiences and treatments of trauma victims of the Biafra war. The focus is on the loss of Biafra as an assumptive world; a loss which was not perceived as such during and immediately after the war but now evident in its 'representation' in the political discourse of the present.

The Biafra war, as an event and Biafra, as assumptive world, continue to disrupt individual and collective memories and as such tend to 'frame' state and politics in Nigeria as evidenced both in political discourse and political practice. The continuous debate on the creation of more states in the Igbo states is a case in point. The concept and theory of assumptive world is utilised in this paper to give a perspective on Biafra as a meaningful object. That is, Biafra as a purpose to the Igbo. Seeing Biafra in this light presupposes an assumption or beliefs that ground, secure, or orient the Igbo. The assumption is the aspects of the Igbo being, their identity. Thus the loss of Biafra is a traumatic one. But what makes 
the trauma cultural? Simply, the trauma is cultural above all else because of the shattering of the assumptive world of the Igbo. It qualifies as such because of the shattering of aspects of the Igbo being. The critical notion here is assumptive world which allows for an insight into the social and cultural repercussions of the fact of the Igbo not being able to realise Biafra. This immediately distinguishes the suffering resulting from the war experienced by individuals and the pain of the loss of what is meaningful which manifest in the anxieties of the Igbo in current political discourse. A brief elaboration follows.

The initial conception of assumptive world by Parkes (1971:102) defines it as "the only world we know and it includes everything we know or think we know. It includes our interpretation of the future, our plans and prejudices. Any or all of these may need to change as a result of changes in the life space." It is an "organised schema .... Which contains everything that we assume to be true [about the world, the self, others] on the basis of our previous experience. It is this internal model of the world that we are constantly matching against incoming sensory data in order to orient ourselves, recognise what is happening, and plan our behaviour accordingly" (Parkes, 1988:56). As Kauffman (2002:2) suggests, this implies a conception of a basic organising principle of human experience and beliefs and temporality. He adds that Parke's concern is with the psychology of change, specifically the psychology of healing from the wound of loss that is present in change. Assumptive worlds are constant internal contracts and change is the disruption of the constancy of these constructs ..... The concept of the assumptive world is, in the broadest sense, a principle of the normative constancy and belief, a constancy principle of the psychological organisation of the human world and one's experience of oneself and the world. The assumptive world is the principle of the conservation of psychological reality" (Kaufmann, 2002:2). In other words, it is the 'ordering principle', as he puts it, for the construction of one's world.

As an 'ordinary principle' one can argue that it's meaningless in ones being becomes apparent in that it is the instrument with which our 'reality' is constructed yet, it is itself that 'reality' in an existential sense. In Janoff-Bulman is the suggestion that assumptive world is illusion and it is through this that culture is constructed. This would mean, if read correctly, that culture is in a sense illusion, where illusion is about beliefs. As she writes, at the core of our internal world we hold basic truths of ourselves and our external world that represent our orientation towards the total push and pull of the cosmos. She adds that "Our penchant for preserving rather than changing knowledge structure suggests the deeply embedded, deeply accepted nature of our beliefs about the benevolence and meaningfulness of the world and our own self" (Janoff-Bulman, 1992:51). When this, that is, the normative constancy of beliefs, is disrupted, then we have 
a loss of our assumptive world; a loss that is one of beliefs about meaningfulness and self-worth. For her, therefore as Kauffman (2002) remarks, the concept of assumptive world is about loss of basic valuations. But these valuations, one might add, do not necessarily have to be individual but could be collective valuations. This is to suggest that the concept of the assumptive world is not one that applies exclusively to the experience of an individual but also applicable to that of the collective.

In fact this point is implicit in some of the major contributions to the concept and indeed, in quite a few, somehow explicit, especially in those that 'widen' the lens beyond psychology. Becker's (1962, 1971) contribution, for example, factors what can be referred to as the 'anthropological' and indeed the 'sociological', in essentially what is a psychological concept. This would seem immediately understandable given that he drew extensively from anthropology to explore the logic of transference in therapy. Transference, as is well known, is a language of psychoanalysis, which refers to what psychoanalysts consider the overblown sense of power and importance that a patient projects upon an analyst in therapy. Its analysis is considered very useful in getting into a patient's unconscious conceptions of power and power relationships. Becker literally takes transference out of this psychoanalytical context and expanded it to a wider relational context, a psychology-sociology movement. For Becker, the logic of transference applies to some of the relationship in which we engage in society as people and symbolic relationships. Transference thus occurs whenever an "exaggerated sense of power is used to cope with and calm an otherwise sense of anxiety" (Lietchy, 2002:88). The symbolic relationship to which its logic applies is of immediate relevance here because it is the relationship between a person and material objects; objects that we ascribe symbolic importance, for example, ethnicity, which is often used, in many contexts, as a protective shield. Becker's expanded notion of transference is thus "a way of life in which we all participate" (Lietchy , 2002:88).

Becker's contribution as found in his excursion into the problem of 'man', (1971, 1973 and 1975) revolved around five questions which he asked in an earlier exploration (1962): What are the innate dispositions of human beings? What is the relationship between human beings and nature? What is the direction in time of the action process? What type of personality is most valued? What is the dominant modality of human relationship? These questions, if the reading is correct, are essentially Maslow-ean. As is generally known, Maslow writes about hierarchy of needs; this, certainly, is not the same as Becker's five questions but the concern would seem similar in the sense in which it is about what is good for an individual's survival needs; healthy survival, if one can qualify. In Becker's view, what he referred to as our cultural worldview, that 
is, our constructed assumptive worldview as interpreted by Lietchy (2002:85) "functions in the manner of a transference relationships. In its very character of normalcy and taken-for-grantedness, it acts as an integral anesthetizing buffer against unconscious and repressed death anxiety."

The Igbo as an ethnic group in relation to other ethnic groups in Nigeria would in Becker's conception of transference be read as participating in transference which other ethnic groups are similarly participating in. The transference, in the Igbo case, would seem to be in the sense of the Igbo self-worth, which they tap upon to bat off their anxiety as a 'marginalised' group. A gaze into the significance of the Igbo person's place of origin, importance of appropriate and permanent marriage, the value of children, reveals, to a considerable extent this self-worth. As Smith (2005:31) correctly notes: "When the Igbo speak about the things that distinguish them from other ethnic groups in Nigeria, they frequently cite the permanence of Igbo marriage. Great pride is expressed about the fact that Igbo pay high bride wealth, about the expectation that elaborate traditional ceremonies are required in order for marriage to be socially legitimised and publicly recognised, and about the shared sense that divorce is stigmatised and relatively uncommon".

This points to the issue of the loss of Biafra as cultural trauma. How is this loss to be understood? If we take the preceding arguments into account, the loss is not only recollected through the facts of the loss of the event, the war, but recalled in the perceived marginalisation of the Igbos. In this, the meaning of Biafra comes to the fore. This point is critical in making sense of the point about the existence of a cultural trauma. So, what does Biafra mean?

\section{The Meaning of Biafra}

Based on the preceding description of cultural trauma, it is possible to claim that the current politics in Nigeria and the perceived marginalisation of the Igbos re-evoked and intensified the spectre of Biafra, an existing cultural trauma. One can suggest further that the cultural trauma exists because of the 'threat' to aspects of the Igbo identity.

Here the utility of the theory of assumptive world becomes apparent: as was earlier indicated, it is particularly useful in the notion of Biafra as a locus of articulation of an Igbo identity. When subtly recollected in political discussion, it suggests a construction of 'collective memory', a notion which Olick (1999) indicates is tied to delineation of group membership. According to him, it is "not just that we remember as member of groups, but that we constitute those groups and their members simultaneously in the act (thus re-membering)" (1999:342). 
The war that terminated Biafra, the still-born, is widely seen as an ethnic conflict in the sense in which the goals of at least one conflict party are defined in exclusively ethnic terms and which the primary fault line of confrontation is one of ethnic distinctions. The goal was the secession of the south eastern part of Nigeria from the rest. It was a goal given energy by what might be better referred to as a sharpened politics of ethnic difference, anchored, in an invigorated political movement. Biafra secession was thus the political movement of an ethnic group that hoped to succeed and establish an independent state of its own on the territory on which it lived. It was a war that in general, was between the HausaFulani of the North and the Igbo of the South East of Nigeria. Whether or not the war can be neatly wrapped as such is contentious given what has been noted by some observers that the Igbo were catalyst in the formation of a nation among culturally related peoples of the eastern part of Nigeria (see Diamond, [1970] 2007, for example). The narratives of the war by Igbo in their recollections is said to reveal that the notion of a pan-Igbo ethnicity only solidified in the wake of Biafra (Smith, 2005).

The immediate circumstances that led to the war have been well documented (see for example, Cronje, 1972; De St. Jorre, 1972; Obasanjo, 1980; Ekwe-Ekwe, 1990) but a brief discussion of this in the form of highlights will suffice. The account provided here is taken mostly from Nkpa (2001) and John de St. Jorre (1972). The war started in 1967 and ended in 1970. The $15^{\text {th }}$ of January 1966 is a significant date in terms of its precipitation. On this day, Nigeria witnessed the first of the many military coups that have become part of its history. A section of the Nigerian army staged a coup in which the Prime Minister, a northerner, top-ranking politicians from the western and northern parts of the country were killed. There were no politicians in the eastern part, mostly inhabited by Igbo and other minority ethnic group who were killed. The coup brought to an end the first democratically elected government and brought in the first military government headed by an Igbo general. The fact of this generated a lot of tension, in particular, in the northern part of the country. The general perception was that the Igbo overthrew the government because it was headed by a Hausa. What was thus 'sown' in the minds of the Hausas was the idea of an assertion of the power of an ethnic group, the Igbo on the body politics of Nigeria.

Almost five months later as this perception gained wide acceptance, a massacre of the Igbo resident in the northern part of the country was carried out by the northerners. Then on the $29^{\text {th }}$ of July of the same year, there was the second coup in which the Igbo military head of state, General Ironsi and the Yoruba military governor of the Western Region, Lt Col Fajuyi, were killed and a northerner, General Gowon became the new head of state. This did not stop the massacre of the Igbo in the north by northerners; the months of August, September and 
October of 1966 saw waves of massacres which subsequently led to what could be described as the great flight: Igbo resident in northern Nigeria moved in thousands back to eastern Nigeria, their homeland. About 2 million Igbo were estimated to have been in flight (Nkpa, 2001). This created a refugee crisis, which the military head of government, General Gowon and the Igbo soldier, General Ojukwu, who had assumed leadership of the Igbo, could not resolve. In January 1967, efforts were made to draw a new constitution for Nigeria to replace the British-influenced pre-independent constitution but this failed. Almost four months later, on the $30^{\text {th }}$ of May 1967, General Ojukwu declared that the eastern part of the country had seceded and that part was a new country, Biafra. He effectively became the head of state of the new country. The secession was considered a rebellion by the government of General Gowon and on the $6^{\text {th }}$ of July, 1967, a military operation started against Biafra. The war thus officially started on that day. In January 1970, the war ended and Biafra was split into four states within the Federation of Nigeria.

The central narrative in the literature on Biafra is one of grand scale violence, ruination,in Diamond's ([1970]2007) phrase, of a "national culture at the moment of birth", massacre (it is variously estimated that up to 2 million people, mostly the Igbos, died in the war) and mass starvation with the resultant trauma. The resultant trauma is not disputed even though there is hardly an extant literature on this; nevertheless one can make this claim given that there is hardly any war, no matter its scale, that does not bring about physical and psychological wound. The Biafra was not an exception as it left many physically and psychologically wounded. Psychologically, as previously mentioned, it induced pain, anguish, fear, loss and grief to the destruction of a coherent and meaningful reality, which is the main point of the present paper.

Biafra, as lodged in the psyche of the Igbo, arguably, therefore, represents, being unchained; unchained from an entity of cultural antipathy brought about by the English colonisers. This entity was a 1917 creation when the northern part was amalgamated with the southern part. For the English, the north was the model that informed their construction of Nigeria. Its feudal character, some writers have been quick to point out, resonated with the English unlike what obtained in the Yoruba-speaking south-western part and the Igbo-speaking south-east. It is significant to note that the English, as carriers of autocracy, then, and zealous propagandists of democracy in contemporary times, met what has been described as a well-articulated political structure, with a complex system of chieftaincy among the Yoruba and a subtly organized autonomous hamlets in the east, which one of the foremost Nigerian historians, Dike (1965, cited in Diamond, [1970] 2007), described as "excess of democracy". As a people, the Igbo celebrated self-achievement more than revel in inherited or ascribed 
status more notable a characteristic of a feudal society of which the HausaFulani society in the north has been described. It is this self-worth that was to enable them to re-integrate into Nigeria after the war with less support from the Federal government as claimed by Igbo writers (see for example, Ekwe-Ekwe, 1990; Amadiueme, 2004; Ikpeze, 2004).

The suggestion here is that the celebration of self-worth as distinct from ascribed status formed part of the fundamental 'building blocks', if it can be so described, of the war. Not only was the north feudal, it was predominantly Islamic. As Diamond ([1970]2007: 349) writes, "Northern society was hierarchical and, at least in the upper castes conservatively Islamic. Paradise awaits the true believers the goal is the protection of the status quo. In the view of the Northern Muslim leaders, Nigeria was conceived as a theocracy". What obtained, arguably more than anything else apart from religion, in the entity that was created, were two cultures: autocracy and 'excessive democracy'. In fact religion seemed intertwined in the two cultures: autocratic Islamic north and democratic Christian south. Given these, the fundamental values of democracy seemed difficult to take root. Indeed, as Uwazurike (1997), has argued, there was an absence of genuine democratic ethos of mutuality and compromise. He notes that "for democracy to prevail in the unscripted struggle for power with authoritarian types, they must always anticipate the onset of an "unsolvable crisis" - and be able to reequilibrate through timely compromise" (1997:267). It was thus inevitable that a 'clash of culture' would occur.

The sharpening of the two cultures was evident in the political governance of the country immediately after political independence in 1960. The model of governance adopted after independent derives from the liberal model dominant in the 1950s. This has been described as a "progressive adaptation of some western model of which the most important have been the British parliamentary or the American presidential systems"(Uwazurike, 1997). Uwazurike (1997) suggested also, and forcefully, that this was an acceptance rather than a proposed model by the nationalists in deference to the colonial British authorities. He added, rather dismissively, that the acceptance was because the tripartite ethno-political class - the Yoruba, Hausa-Fulani Moslems and the Igbo - were "anxious as they were for independence on a "platter of gold", that is, without any struggle that might have shaped future directions"(1997: 271). The three ethnic groups expressed themselves politically along ethnic lines and attained power along those lines; while it has been argued that ideological leanings and interest-articulation are significant in analysing the various political alliances and networking evident in Nigeria's political history, a more salient factor and scarcely acknowledged and explored one contributed in a great measure in shaping the political landscape, I argue, is the two cultures, which were undeniably ethnically 'coloured'. 
The literature on Nigerian politics show that the tendency in Nigerian politics has been the attempt to create a "self-contained regional utopia within which a dominant ethnic coalition - there are no pure ethnic groups really - in a paternalistic fashion, serves as the constellation around which revolve the lesser formations" (Uwazurike, 1997: 272). Indeed, this is what seemed to apply as expressed in the phrase "Nigeria is a mere geographical expression" brought together by the British colonisers. It is significant that this phrase is still very much uttered in current political discourse just as it was many decades back and which, as has been noted, was interpreted in the 1990s by a leading northern politician, Maitama Sule as follows:

In this country, all of us need each other. Hausas need Igbos, Igbos need Yorubas and the Yorubas need the northerners. Everyone has a gift from God. The northerners are endowed with leadership qualities. The Yorubaman knows how to earn a living and has diplomatic qualities. The Igbo is gifted in commerce, trade and technological innovation (cited from Uwazurike, 1997: 273).

The significance of the preceding point is that the cultural basis of Nigerian politics is salient in exploring what made Biafra, that, which was lost to the extent that it was traumatic in the collective psyche of the Igbo. The point about the Igbo being gifted in commerce and trade is borne out by the fact that they are the most migratory of Nigeria's ethnic groups, settling in large numbers in all of Nigeria's major cities, and establishing their markets anywhere it seems reasonably possible to make a profit (Smith, 2005). This fact is taken to argue that the Igbo invest more in 'one Nigeria' than any other ethnic group (see Smith, 2005, for example). However, the point is stressed, that the cultural construction of the "Igbo identity and the strength of political ties to place of origin simultaneously produce an ideology of ethnic nationalism" (Smith, 2005). How did this ideology of 'ethnic nationalism' develop from the 'excessive democracy' of village communities referred to earlier?

The answer to this would lie in the making of Nigeria by the British and the experience of the Igbo in this process. Of immediate significance here is the process of what is referred to as 'tripartition' (Ademoyega 1981 as cited in EkweEkwe, 1990) in Nigerian politics. This process began in 1946 with the colonial government's policy of integrating the northern provinces into the colonial administration and the implementation of the Richards Constitution. Earlier before this, the north and south of Nigeria were governed separately despite the amalgamation of both into what became Nigeria in 1914. The Richard Constitution provided the administrative framework for governance: Nigeria 
was split into three administrative regions - the east, west and north. There was nationalist opposition to this coming mainly from the National Council of Nigeria and the Cameroons (NCNC) considered to be essentially an Igbo party, though, the leaders were from different groups in Nigeria and, the National Youth Movement (NYM) based primarily in the west and led by Awolowo. As Ekwe-Ekwe (1990) noted, the two parties had a different strategy of opposition: the NCNC launched a nationwide campaign while the NYM was only critical of the fact that Nigerian leaders were not consulted before the enactment of the decree.

The point here is the regionalism of the NYM and the nationalism of NCNC took root in Nigerian politics. This was exploited by the British colonial administration in the 1950s when the push for independence became more 'feverish'. During this period, the dominant parties, the Northern Peoples Congress with membership restricted to the Hausa-Fulani, the NCNC, now with predominantly Igbo membership and the Action Group a predominantly Yoruba party became highly politically active in the scheme of things. Ekwe-Ekwe (1990) argued that the NPC worked to oppose Nigeria's independence and only shelved this in 1957 when the British gave it the assurance that it would hold the first post-colonial government. The AG, Ekwe-Ekwe adds, worked to ensure the emergence of a post-colonial Nigeria divided into regional groupings. The question is: why would this be the case? What one hardly gets from those writers who give this interpretation is the cultural basis of the politics of the parties. The NPC was principally, as Ekwe-Ekwe (1990) remarked, a reincarnation of the aristocratic oligarchy of Fulani political supremacy which held power before British colonialism. Its ideology is regional 'separatedness' mediated by Islam. This shaped its worldview and could, hardly, have not coloured its politics. It would be inconceivable to think that such a party would yield to the unitary constitutional arrangement favoured by the increasingly Igbo-dominated NCNC with its western-educated leadership now mentally steeped into British parliamentary framework of 'doing things'.

The emerging two cultures in relation to the politics in Nigeria suited the British colonial administration very well. For example, as Ekwe-Ekwe (1990) highlights, when the NPC took political hold of the north in the 1950s, it proclaimed a policy of 'northernisation' which excluded southern Nigerians from jobs in the region's public service. Foreigners, particularly Britons, and quite often officials in the employ of the civil services in the south, but who could not cope with the increasingly nationalistic politics of the time, were readily given posts in the north which excluded Nigerians of non-northern nationalities. The north continued to offer this haven for a number of British ex-southern civil servants and other professionals, in addition to British subjects from elsewhere, 
well beyond Nigeria's independence in 1960" (p15).

The 'regionalism' of Nigerian politics, brought about by the Richards Constitution, deepened. The political parties, in particular, the NCNC, NPC and $\mathrm{AG}$, became increasingly chauvinist and exclusivist. "What was now in position were regional quasi-autonomous political entities which exhibited the most unimaginable rivalries and, quite often, conflicts with each other, and whose relationship with the centre, varied from the ambiguous to undisguised opportunism. In this dispensation, the political control of the centre by any of the main parties became the necessary condition for the consolidation of power in its regional fiefdom, itself a precondition for existence" (Ekwe-Ekwe, 1990: 16).

As the regionalism deepened, the NCNC as indeed other political parties became increasingly less nationalistic though the quest for independence did not evaporate. What was apparent was that the political elite showed strong allegiance to one of the three regions - north, east and west. The allegiance was beneficial economically to the elite because with the growth of regional economies that resulted from the deepened regionalism, they acquired massive wealth. Ekwe-Ekwe (1990: 19) made this remark when he writes "that the regional autonomy of the era provided the varying strata of the emerging Nigerian merchant and bureaucratic classes the first opportunity in history to attempt some form of accumulation of their own, albeit at the behest of the British colonial government which now chaired the pre-independence 'transitional' governments in Enugu, Ibadan and Kaduna (as well as the central one in Lagos) between 1951-1959." Of significance is that ethno-nationalism sharpened during this period underpinned and given direction by wealthy political elite. Under this condition, the orientation to tie oneself to one's place of origin for success in business and the professions would develop and it is not out of place to suggest that such was the case.

The tie to the place of origin implies a premium on 'having people' as Smith (2005) has put it. It manifests in marriage and reproduction. The importance of this has been documented and stressed by anthropologists (see for example, Fortes, 1978). The Igbo, numerous writers have not hesitate to point out, are by no means the only ethnic group in Africa that places premium on place of origin; the Yoruba, it has been observed, are similarly known for such a premium (Oloyede, 2002). However, as Igbo historians have been quick to stress, what is perhaps distinctive is the affective and moral obligations to the communities, their extended families and affines (Smith, 2005; Chukwuezi, 2001; Isichei, 1976), which formed part of the assumptive world that I argue, was to be 'disturbed' in a long duree in the entity Nigeria. The 'disturbance' came in the form of an absence of 'having people' in the political economy of the entity, Nigeria. Smith's 
(2005:32) notion of 'having people', whilst having a cultural bent, has to be seen as more than that in the scheme of things in the entity that was created by the British. The Igbo, as noted earlier, are 'gifted traders'. But to be gifted is hardly enough for success of any kind; there must exist the condition that allows for the 'gift' to translate into success. The British strategy of 'divide-and-rule' in the form of the Richards Constitution provided the condition. As pointed out earlier, the British gained from it; so did the leadership of the Nigerian political parties whose elite status became more confirmed in their politics of 'regionalism'. For Nigerians as Dudley (1982: 47) remarked:

"As an employee, he now found that the level of his tax varied with the region in which he resided: he paid the most in income tax if he resided in the East and the least if his residence was in the North. And as a farmer growing export crops, he found that the price he got for his produce varied with the region in which the produce was sold. Thus, for example, he got more for his cocoa if he sold it in the East - which grew little cocoa - than if the same cocoa was sold in the West. As a parent, with children of school=going age, he found that if he resided in the West, he did not have to pay fees for his children in primary schools but he had to do so if his place of abode was in the East or in the North."

For the Igbo, a presumed gifted people in commerce, the disarticulated character of the political economy of Nigeria, was the opportunity that they could hardly resist and the point about their migratory tendency can be understood in this context. Their movement and residence in the North, despite its 'hostility' to the southerners was not a deterrent. They were mostly traders and involved in commerce especially because of the 'politics of exclusion' from the expanding public service in the north. The North was haven for them: any businessperson would cherish a low-tax context to operate as it allows for maximisation of profit.

Further, to trade and make a success out of it requires among many things, the condition that would enable it which would include access to capital. Such an access is created by government policies which make it easier for channels as the financial institution to make capital available.

Business also needs government tender thus making powerful those who award tenders. It thus becomes an essential 'to have people' who will make it happen. Patronage becomes in this sense critical in defining success. For a people anchored in 'having people', such an essential is a given. Networks of patronage are created and navigated as many writers have demonstrated through kinship ties among the Igbo. This is part of the assumptive world of the Igbo. What 
therefore makes Biafra that, which was lost, is its 'constituting power' in the Igbo being. How can this be read as traumatic? This is discussed in the section that follows.

\section{Biafra as a Traumatic Loss}

Contemporary political arrangement in Nigeria continues to face the unresolved problem of how best to keep it as an entity in which ethnic groups will not feel marginalised. It is this feeling of marginalisation, as would seem clear in the discussion up to this point that laid the foundation for the attempt at secession and the subsequent shattering of the assumptive world of the Igbo. The feeling is translated into action in some cases as evidenced in the inter-ethnic violence across the country. Quite a number of ethnic groups fight the Nigerian nationstate for more rights and a greater share in political power and economic wealth, as well as each other over resources and the preservation of their distinct lifestyles. For example, we see the Ijaw and the Itsekiri in the Niger Delta at each others' throats; the Ilaje and the Ijaw; the Yoruba and the Ijaw and the Yoruba and the Hausa in the south west, between Yoruba and Hausa in the north, the Tiv and Jukun, and Fulani and Kuteb in the middle belt of the country, and between the Fulani and Berom in the Plateau region. In addition is the perennial fighting between the Muslims and Christians in the north, evidence of the two cultures as argued earlier.

The dynamics of the conflict are almost identical but in the case of the Niger Delta, it is more related to what has been referred to as the material value of the territory (Wolff, 2006). Since the early 1990s, there has been documented evidence of continuous conflict in this part of the country, which is the source of most of the country's oil wealth, killing, as some political commentators estimated, around a thousand people per year (Wolff, 2006). The case of the Niger Delta, it is important to point out, seems rather complex in its conflation of ethnic and territorial claims. The population of this part of Nigeria is estimated to be well over 7 million people who belong to five main ethnic groups variously in conflict with multinational oil corporations - Chevron, Exxon Mobil and Shell - over land and compensation for environmental damage, with the state over the share that they receive in their homeland's oil wealth, and with each other over land ownership of oil exploration areas. Of note, one needs point out, is that, at the core of these inter-ethnic conflicts is the significance of territory as a symbol of individual and collective identities, its strategic value as a source of control and influence. The significance of territory stems also from the fact that it can be used and indeed was used in the Biafra case as a defining criterion in 
relation to the Igbo identity - the great flight that was mentioned in the earlier section, was one back to the homeland. It is apparent that territory was also the basis of the political entity, Biafra, and a potent source of mass mobilisation before the war in the form of regionalism and the Biafra nation. What this suggests is that territorial components form a significant dimension of ethnic identity, primarily in the form of actual homelands to which an ethnic group attaches importance as its origin. In fact it is a general point in political science literature on ethnicity. Territory possesses, as Wolff (2006) suggests, certain 'values in and of itself' and the Delta conflict, seems to be an evidence of this point. The central point of note in making this statement is that in this context, inter-ethnic relations must be conceived of more broadly than the traditional majority-minority relations that one finds in the analysis especially in relation to disputed territories. We have seen in the case of the Delta part of the country that it is inhabited by members of more than one ethnic group. What is clear is that the inter-ethnic conflicts are not ones in which groups claim the right to self-determination equating independent statehood with such claims. In fact not all the ethnic groups are in a situation in which independent statehood or increased autonomy within the Nigerian nation-state is a possible or desirable option although one hears quite relatively often comments that all ethnic groups should go their separate 'ways'.

The Igbo experience is, however, exceptional. It is, in the discourse of nationalism, an ethnic nationalism as distinct from the civic nationalism. This distinction immediately raises the question of the relationship between ethnic groups and nation. According to Wolff (2006), the key distinction lies in their relationship to the state. He writes: "Nations by definition, require a state to fulfil their potential; ethnic groups do not and historically have not. This is not to say that ethnic groups have always existed or that the make-up of their identity does not change over time..... Yet, in the same way in which ethnic groups and nations are distinguishable from each other in their relationship to the state, so their political relevance can be determined, at least in the contemporary world of nation state. Ethnicity does not have to matter politically, nationalism does" (2006:54/55). Nationalism he argues is not necessarily tied to ethnicity; in this sense, civic nationalism is thus more virtuous and liberal, whereas, ethnic nationalism is seen as dangerous and exclusive. In civic nationalism, all citizens are considered equal regardless of their ethnicity, cultural or religious, or linguistic background and have the same rights and responsibilities (Wolff, 2006). The state in this conception is 'blind' to difference in the allocation of resources. As Wolff (2006) was quick to point out, this classically liberal notion of civic nationalism advocates the minimal and, in a broader sense, secular state, where everyone is equal in the public sphere and where religion, language, 
ethnicity etc., are a strictly private matter. However, as he further stated, civic nationalism "by default, advantages majority cultures: their language, traditions, customs become 'official' whereas those of minorities are relegated to the private sphere, and it is the responsibility and choice of individuals whether or not they want to maintain certain aspects of their identity that 'diverge' from the national identity, which although defined as civic, is in fact nothing but the majority's ethnicity writ large.”. (Wolff, 2006:52/53). Civic nationalism creates an illusion of binding all ethnic groups together but it leads to ethnic conflict as the interethnic conflicts in Nigeria have shown.

Ethnic nationalism derives from the difference which is de-emphasised in civic nationalism. Unlike civic nationalism, it is far less accommodating of difference because it hardly allows for equality in the public sphere and tends to be discriminatory against members of ethnic groups other than the dominant group because they appear different. As pointed out earlier, there is a general consensus that the Biafra war was an ethnic conflict. It was, in the context of preceding discussion, an Igbo ethnic nationalism. It was about the assumptive world of the Igbo. The war, at a general level, arose from the evaluative significance accorded by the Igbo to acknowledged differences between the Igbo and the Hausa which was played out in public rituals of affirmation and political power relations. Conventional explanation would have us believe that unlike the other two bigger ethnic groups in Nigeria, the Hausa and the Yoruba, the Igbo were committed to the entity Nigeria as a nation-state uninhibited by "loyalty to any pre-existing archaic political structure" (Diamond, 2007:349). However, they lost faith in the possibility of a unified Nigerian nation and expressed their sense of nationality in the creation of Biafra.

The expression of a nation by the Igbo and the loss of that meant the shattering of their assumptive world. As Diamond (2004:359) puts it "It meant the collapse of their symbolic universe and living on sufferance in a state that had used every conceivable means to reduce them to its own aspirations and pace, that is to say, to the Nigerian common denominator as it had been determined by colonial powers." This somehow captures the trauma, the damage to their assumptive world. The assumptive world of the Igbo derive from their being; their cognitive representation of this being; who they see themselves as, how they organise themselves and their sense of connection and belonging to their social world - their reality. The damage to this world comes in the form of the breaking of their constitution as Biafra, a cognitive 'representation' of their being; the entity Biafra was to bring a sense of belonging and connection in a manner that the entity, Nigeria, would not - one that would cohere the Igbo being; their relation to themselves; their being attached to themselves. Biafra thus gives the power of making real, constituting, constructing and bringing forth an Igbo nation. 
In the wake of the loss of Biafra, damage was done - the power to make real is shattered, the bringing forth of the Igbo nation is lost, a nation that brings connection to the Igbo. Trauma, collective trauma, sets in. How is this trauma mediated? This is answered by way of a short concluding remark.

\section{Concluding Remark}

In concluding, it needs to be pointed out that the concept of trauma does not occupy a key position in the discussion about Biafra, though one finds it implicit in some recent writings (see for example, Smith, 2005). This absence illustrates the marginal status of the concept in the discussion of the Biafra war. Much of the writings are overwhelmingly political which is scarcely surprising. It is, quite rightly, considered a political issue.

Given this, a psychoanalytically 'occupied' term would hardly be considered of utility in providing an insight into a still contentious and contested political arrangement in Nigeria. However, the fact of the undertone of some of the contentions which reflect the social repercussions of historical traumata requires the application of the concept of trauma. This is what has been attempted in this paper.

One can only say that the collective trauma of the loss of Biafra is mediated through the continuous practices of an aspect of their self worth. The Igbo are a migrant people. They are the most migrant of all the ethnic groups in Nigeria and can be found in all corners of the country.

The fact of the loss of Biafra and the anxiety that the Igbo have in contemporary Nigeria has not diminished their migratory 'instinct' to other parts of the country, especially to the north of the country where they were massacred. In such places, they assert their self worth through entrepreneurship and lineage organisations that regularly meet. This gives a sense of community and continuity and "extends the obligations of kinship across the Nigerian political and economic landscape" (Smith, 2006:37). The reproduction of the social structural form in the sense of lineage meetings provides the Igbo the security and protection from the extreme anxiety-provoking awareness of their perceived marginalisation.

They are able to 'exploit' the networks of kinship, affinity and community to 'get on with life'. Getting on with life sits at the fore of the Igbo consciousness. It is a culture capital, in the Bourdiuean sense anchored in an Igbo saying which Amadiueme (2004: 50) points at: 'Onye ajulu ana ju onwe ya?' - when others reject or abandon you, you don't also abandon yourself." and serves as mediating the trauma of their loss of Biafra. Significantly, in getting on with life is the Igbo memory of Biafra. 
They draw on these memories when faced with hostilities. On such occasions as religious hostilities, for example, they recall Biafra. Yet Biafra was what was lost and the loss a trauma for them. This 'oddness' creates in itself a sort of sublimated psychological energy which is the 'real' source of their mediation of the traumatic loss.

\section{References}

Ademoyega, Adewale 1981, Why We Struck: The Story of the First Nigerian Coup. Ibadan: Evans Brothers Nigerian Publishers

Alexander, J. C. 2004, "Toward a Theory of Cultural Trauma", pp 1-30 in Cultural Trauma and Collective Identity, edited by J.C Alexander, R. Everyman, B. Giesen, N.J. Smelser, and P. Sztompka. Berkely, CA: University of California Press

Amadiume, Ifi 2000, The Politics of Memory: Biafra and intellectual Responsibility, pp. 38-55 in The Politics of Memory: Truth, Healing and Social Justice, edited by Ifi Amadiume and Abdullah An-Na'im. London: Zed Books

Becker, E. 1962, The Birth and Death of meaning: A perspective in psychiatry and anthropology. New York: The Free Press

Becker, E. 1971, The Birth and Death of meaning: An interdisciplinary perspective on the problem of man New York: The Free Press

Becker, E. 1973, The Denial of Death, New York: The Free Press

Becker, E. 1975, Escape from evil, New York: Free Press

Chukwuezi, Barth 2001, "Through thick and thin: Igbo rural-urban circularity, identity and investment", Journal of Contemporary African Studies 19 1, pp. 55-66

Caruth, C.1996, Unclaimed Experience: Trauma, Narrative and History. Baltimore, MD: Johns Hopkins University Press

Cronje, Suzanne, 1972, The World and Nigeria: The Diplomatic History of the Biafra War. London: Sidgwick and Jackson

de St. Jorre, John 1972, The Nigerian Civil War. London: Holder and Stoughton

Diamond, Stanley, 2007/1970, Who Killed Biafra? Dialectical Anthropology, 31, pp. 339-362

Dudley, Billy 1982, An Introduction to Nigerian Government and Politics. London and Basingstoke: Macmillan Press

Ekwe-Ekwe, Herbert 1990, The Biafra War: Nigeria and the Aftermath. Lewiston: The Edwin Mellen Press 
Erikson, Kai 1994, "Notes on Trauma and Community" pp. 183-99 in Trauma: Explorations in Memory, ed. Cathy Caruth. Baltimore: Johns Hopkins University Press

Everly, G. S. (Ed), 1995, Psychotraumatology New York: Plenum Press

Eyerman, Ron 2004, Cultural Trauma: Slavery and the Formation of African American Identity pp.60-111 in Cultural Trauma and Collective Identity, edited by J.C Alexander, R. Everyman, B. Giesen, N.J. Smelser, and P. Sztompka. Berkely, CA: University of California Press

Fortes, Meyer, 1978, "Parenthood, marriage and fertility in West Africa",Journal of Development Studies, 14, (4), pp. 121-148

Harneit-Sievers, Axel and Syney Emezue 2000, Towards a Social History of Warfare and Reconstruction: The Nigerian/Biafran Case in The Politics of Memory: Truth, Healing and Social Justice, edited by Ifi Amadiume and Abdullah An-Na'im. London: Zed Books

Ikpeze, Nnaemeka 2000, Post-Biafran Marginalisation of the Igbo in Nigeria in

The Politics of Memory: Truth, Healing and Social Justice, edited by Ifi

Amadiume and Abdullah An-Na'im. London: Zed Books

Isichei, Elizabet 1976, A History of the Igbo People, London: Macmillan

Janoff-Bulman, R. 1989, Assumptive worlds and the stress of traumatic events:

Application of the schema construct. Social Cognition, 7, pp. 113-136

Janoff-Bulman, R. 1992, Shattered Assumptions: Towards A New Psychology of

Trauma, New York: Free Press

Kansteiner, Wulf 2004, Genealogy of a Category Mistake: A Critical Intellectual

History of the Cultural Trauma Metaphor, Rethinking History, Vol. 8, no 2, June 2004, pp. 193-221

Kauffman, J. 2002, Introduction in J. Kauffman, (Ed.) Loss of The Assumptive World, pp. 1-9, New York: Brunner-Routledge

Landsman, Irene, Smith 2002, "Crises of Meaning in Trauma and Loss" in J. Kauffman, (Ed.) Loss of The Assumptive World, pp. 1-9, New York: BrunnerRoutledge

Leys, R. 2000, Trauma: A Genealogy, Baltimore, MD: Johns Hopkins University Press

Lietchy, Daniel 2002, "The Assumptive World in the Context of Transference Relationships: A contribution to Grief Theory" in J. Kauffman, (Ed.) Loss of The Assumptive World, pp. 1-9, New York: Brunner-Routledge

Lifton, R. J. and G. Mitchel, (eds.) 1995, Hiroshima in America: Fifty Years of

Denial. New York: G. P. Putnam's Son

Niemeyer, R.A. (Ed.) 2001, Meaning reconstruction and the Experience of Loss, Washington, DC: American Psychological Association

Nkpa, Nwokocha, K. U 2001, Rumours of Mass Poisoning in Biafra, 
Obasanjo, Olusegun 1980, My Command: An Account of the Nigerian Civil War 1967-70. London: Heinemann

Olick, J. K. 1999, “Collective Memories: The two Cultures” Sociological Theory, 17 (3): 333-48

Oloyede, O. 2002, Mental illness in culture, Culture in mental illness;: an anthropological view from South Africa, Medische Anthropologie Vol 14, 2, pp 251-274

Parkes, C.M. 1971, Psycho-social transition: A Field of Study. Social Science and Medicine, 5, pp. 101-115

Payne, J. D., L. Nadel, W. B. Britton and W. J. Jacobs. 2004, The Biopsychology of Trauma and Memory, pp. 76-128 in Memory and Emotion, (Eds) D. Reisberg and P. Hertel Oxford: Oxford University Press

Piver, H. L. and Prigerson,, H. G. 2005, Traumatic Loss, complicated grief and terrorism. Journal of Aggression, Maltreatment and Trauma, 10, pp.277-288

Reisberg, D. and P. Hertel (Eds.) 2004, Memory and Emotion, Oxford: Oxford University Press

Smelser, Neil 2004, Psychological Trauma and Cultural Trauma pp. 31-59 in Cultural Trauma and Collective Identity, edited by J.C Alexander, R. Everyman, B. Giesen, N.J. Smelser, and P.

Sztompka. Berkely, CA: University of California Press

Smith, Daniel Jordan 2005, Legacies of Biafra: Marriage, 'Home People' and Reproduction Among Igbo of Nigeria, Africa, 75 (1)

Stocks, Claire 2007, Trauma theory and the singular self: rethinking extreme experiences in the light of cross cultural identity, Textual Practice 21, (1), pp. 71-92

Uwazurike, Chudi 1997, The Search for Stability in Post Civil War Nigeria: On the Prospects of the Rotational Presidency Idea, Dialectical Anthropology, 22, pp. 265-302

Wolff, Stefan 2006, Ethnic Conflict: A Global Perspective, Oxford: Oxford University Press

Zelizer, B. 2002, Finding Aids to the Past: Bearing Personal Witness to traumatic Public Events. Media, Culture and Society 24: 697-714 